\title{
The effects of Global Fund financing on health governance in Brazil
}

Eduardo J Gómez ${ }^{1 *}$ and Rifat Atun ${ }^{2}$

\begin{abstract}
Objectives: The impact of donors, such as national government (bi-lateral), private sector, and individual financial (philanthropic) contributions, on domestic health policies of developing nations has been the subject of scholarly discourse. Little is known, however, about the impact of global financial initiatives, such as the Global Fund to Fight AIDS, Tuberculosis, and Malaria, on policies and health governance of countries receiving funding from such initiatives.
\end{abstract}

Methods: This study employs a qualitative methodological design based on a single case study: Brazil. Analysis at national, inter-governmental and community levels is based on in-depth interviews with the Global Fund and the Brazilian Ministry of Health and civil societal activists. Primary research is complemented with information from printed media, reports, journal articles, and books, which were used to deepen our analysis while providing supporting evidence.

Results: Our analysis suggests that in Brazil, Global Fund financing has helped to positively transform health governance at three tiers of analysis: the national-level, inter-governmental-level, and community-level. At the national-level, Global Fund financing has helped to increased political attention and commitment to relatively neglected diseases, such as tuberculosis, while harmonizing intra-bureaucratic relationships; at the intergovernmental-level, Global Fund financing has motivated the National Tuberculosis Programme to strengthen its ties with state and municipal health departments, and non-governmental organisations (NGOs); while at the community-level, the Global Fund's financing of civil societal institutions has encouraged the emergence of new civic movements, participation, and the creation of new municipal participatory institutions designed to monitor the disbursement of funds for Global Fund grants.

Conclusions: Global Fund financing can help deepen health governance at multiple levels. Future work will need to explore how the financing of civil society by the Global Fund and other donors influence policy agenda-setting and institutional innovations for increased civic participation in health governance and accountability to citizens.

\section{Introduction}

In recent years, a rise in the international financing of health programmes in developing nations have spurred scholars and policy-makers working on global health policy to undertake studies to better understand the effects of these initiatives [1-12]. In particular, a growing body of work has explored how new international funding has benefited health outcomes, influenced policymaking [4,13-15], affected the allocative efficiency and equity of international financing $[3,10,12,13,16]$, as well

\footnotetext{
* Correspondence: ejgomez@rutgers.edu

${ }^{1}$ Department of Public Policy \& Administration, Rutgers University, 401

Cooper Street, Camden, NJ, USA

Full list of author information is available at the end of the article
}

as the additionality of new financing [1]. Others have explored the positive policy synergies created by external investors, that is, donors (such as national governments through bilateral assistance), corporations, individuals (philanthropic), and global financial initiatives (such as the Global Fund to Fight AIDS, Tuberculosis, and Malaria), on health systems, the unintended consequences of these investments [1,6,17-19], and their effects on the design of service delivery [6,12,18-24].

An area that has also attracted interest but where empirical evidence is all but absent relates to the extent to which these external investments have enhanced local institutional capacity $[8,11,20]$. Additionally, few studies have examined how external investments have increased

\section{Biomed Central}


government commitments to combating relatively neglected diseases through inclusive and participatory approaches that foster a closer working relationship between policy-makers and civil society.

Indeed, while the influence of external investments on domestic policy-making, financing, and service delivery has received scholarly attention, the influence of these investments on health governance has been less explored. We address this gap in the literature while providing new insights into how external investments strengthen health governance at multiple levels. We elucidate a new multi-stakeholder approach to health governance, where external investors, such as global financial initiatives, are used to both strengthen and catalyse health governance. The multi-stakeholder approach we describe encapsulates national intra-governmental (i.e., within and between agencies), inter-governmental (i.e., between national and sub-national agencies), governmentalcivil societal, and community-level processes and responses to disease: more specifically, government leadership, policy commitment, and agency cooperation (intra-governmental), inter-governmental cooperation between national, state, and municipal health agencies $[25,26]$, as well as national bureaucratic cooperation with civil society, local community ownership, and community mobilization to achieve common health policy goals $[25,26]$. Empirically, this study examines the case of Brazil, where a limited set of studies have explored the influence of national and sub-national bureaucratic stewardship, community partnerships, and participation in enhancing community-level prevention programmes [27], as well as civic mobilization in enhancing government responses to health [28].

Nevertheless, to date no studies have analysed how global financial initiatives, such as the Global Fund to Fight AIDS, Tuberculosis, and Malaria (henceforth, Global Fund), have influenced this process in Brazil, as well as government commitment to combating relatively neglected diseases, such as tuberculosis (TB). Analyzing the Global Fund is particularly important given its policy commitment to country ownership, multi-stakeholder participation and inclusiveness in its governance structure through civic participation in the policy-making processes via Country Coordinating Mechanisms (CCMs), its Board and committees and dual track financing that enables direct financing of non-state actors as grant recipients [5,18,29-31]. While multilateral lenders, country donors, and global financial initiatives, such as the World Bank, President's Emergency Plan for AIDS Relief (PEPFAR), and GAVI (Global Alliance for Vaccines and Immunisation), respectively, have positively influenced governance, decentralization and healthcare services management, as well as civic mobilization in Brazil for other heath and infrastructural issues - mainly HIV/AIDS [32,33], the Global Fund's contributions to this process has not received sufficient scholarly attention. This study therefore examines the impact of Global Fund investments at several tiers of health governance in Brazil: the national intragovernmental, inter-governmental, government-civil societal and community-level.

As Figure 1 and Table 1 illustrates, when compared to other diseases, TB has posed a particularly high burden in Brazil, ranking third behind dengue and malaria in terms of yearly reported cases from 1980 to 2010, followed by AIDS in fourth place. Several other commonly known diseases, such as hepatitis A \& B, meningitis and yellow fever rank much lower. In a context of increasingly scarce funding for healthcare and the need to respond to multiple diseases [34], the Global Fund's support has helped the $\mathrm{MOH}$ respond to TB.

In response to international pressures and escalating TB cases throughout the 1990s, while the President and Ministry of Health $(\mathrm{MOH})$ had already responded to TB

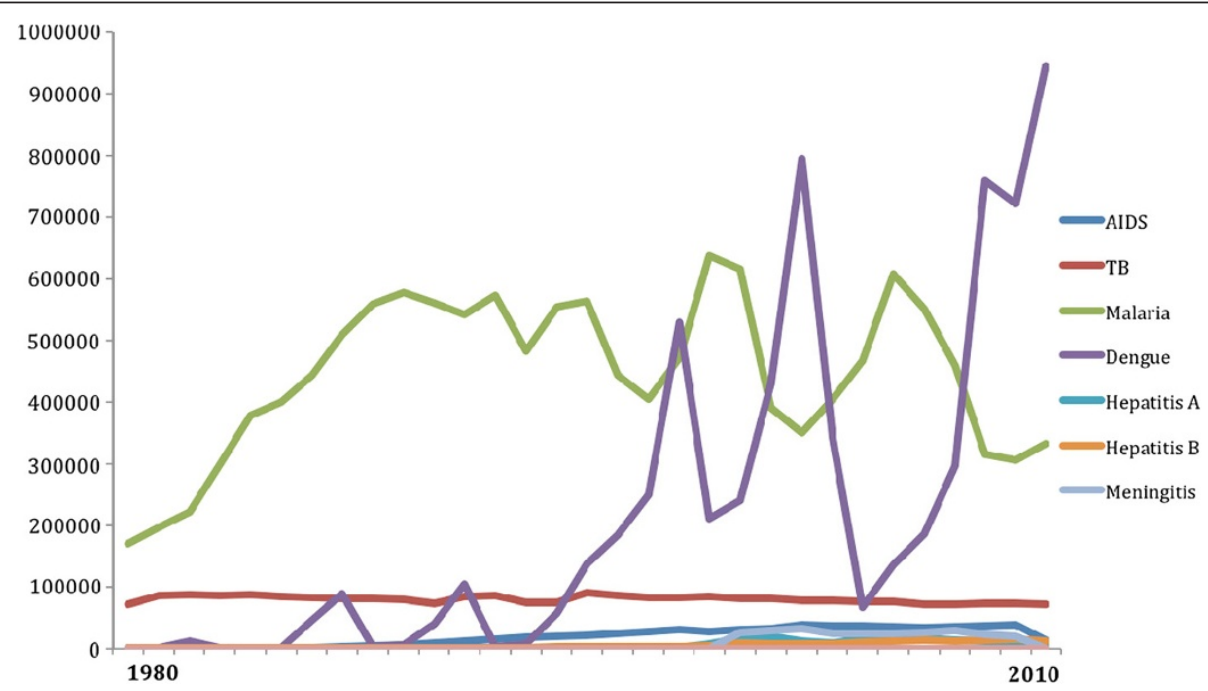

Figure 1 Brazil: number of new cases of key infectious diseases 1980-2010. 
Table 1 Brazil: number of new cases of key infectious diseases 1980-2010

\begin{tabular}{|c|c|c|c|c|c|c|c|c|}
\hline & AIDS & Tuberculosis & Malaria & Dengue & Hepatitis A & Hepatitis B & Meningitis & Yellow Fever \\
\hline 1980 & 1 & 72608 & 169871 & na & na & na & na & 25 \\
\hline 1981 & 0 & 86411 & 197149 & na & na & na & na & 22 \\
\hline 1982 & 10 & 87822 & 221939 & 11000 & na & na & na & 24 \\
\hline 1983 & 41 & 86617 & 297687 & na & na & na & na & 6 \\
\hline 1984 & 134 & 88366 & 378257 & na & na & na & na & 22 \\
\hline 1985 & 554 & 84310 & 399462 & na & na & na & na & 7 \\
\hline 1986 & 1183 & 83731 & 443627 & 46309 & na & na & na & 9 \\
\hline 1987 & 2848 & 81826 & 508864 & 88407 & na & na & na & 16 \\
\hline 1988 & 4598 & 82395 & 559535 & 1570 & na & na & na & 26 \\
\hline 1989 & 6327 & 80375 & 577520 & 5367 & na & na & na & 9 \\
\hline 1990 & 9092 & 74570 & 560396 & 39322 & na & na & na & 2 \\
\hline 1991 & 12135 & 84990 & 541927 & 104398 & na & na & na & 15 \\
\hline 1992 & 15221 & 85955 & 572933 & 1658 & na & na & na & 12 \\
\hline 1993 & 17452 & 75453 & 483367 & 7388 & na & na & na & 83 \\
\hline 1994 & 19189 & 75759 & 555135 & 56584 & 639 & 1275 & na & 19 \\
\hline 1995 & 21980 & 91013 & 564570 & 137308 & 1229 & 1423 & na & 4 \\
\hline 1996 & 25067 & 85860 & 444049 & 183762 & 915 & 1672 & na & 15 \\
\hline 1997 & 27572 & 83309 & 405051 & 249239 & 672 & 2028 & na & 3 \\
\hline 1998 & 30506 & 82931 & 471894 & 528388 & 1649 & 1831 & na & 34 \\
\hline 1999 & 28010 & 84337 & 637474 & 209688 & 8210 & 4204 & na & 76 \\
\hline 2000 & 31493 & 81862 & 615247 & 239870 & 16661 & 7537 & 26931 & 85 \\
\hline 2001 & 31649 & 81182 & 389775 & 428117 & 20671 & 7111 & 30072 & 41 \\
\hline 2002 & 37902 & 77836 & 349965 & 794219 & 12907 & 6239 & 33212 & 15 \\
\hline 2003 & 37619 & 78606 & 405017 & 341776 & 8308 & 6352 & 25431 & 64 \\
\hline 2004 & 36834 & 77694 & 466439 & 66,000 & 17448 & 10246 & 25375 & 5 \\
\hline 2005 & 36009 & 76468 & 607801 & 135,000 & 21580 & 12015 & 25925 & 3 \\
\hline 2006 & 34614 & 72213 & 550917 & 185,000 & 17021 & 12134 & 27543 & 2 \\
\hline 2007 & 35351 & 71825 & 458649 & 296,000 & 13301 & 12049 & 29935 & 13 \\
\hline 2008 & 37465 & 73531 & 315630 & 758051 & 11629 & 13147 & 23623 & 46 \\
\hline 2009 & 38538 & 73082 & 306908 & 721546 & 10743 & 14468 & 21141 & 47 \\
\hline 2010 & 13520 & 71790 & 333429 & 944662 & 5943 & 11700 & na & 2 \\
\hline 2011 & na & 69245 & 263323 & 166,000 & na & na & 19427 & na \\
\hline
\end{tabular}

Sources:

Brazil, Ministry of Health, 2006;

AIDS data obtained from Brazil, Ministry of Health, National AIDS Program, 2011

Tuberculosis data (beginning 203): http://portal.saude.gov.br/portal/arquivos/pdf/casos_novos_tuberculose_1990_2011_16_02_2012_pub.pdf

Malaria data (beginning 2004): http://portal.saude.gov.br/portal/arquivos/pdf/tab_casos_confirmados_malaria_bra_gr_e_ufs_90a09.pdf

Dengue: http://portal.saude.gov.br/portal/arquivos/pdf/informe_dengue_2011_37_39.pdf

http://portal.saude.gov.br/portal/arquivos/pdf/boletim_semana_1_a_30_revisado_03_11.pdf

Years 2004-07: http://portal.saude.gov.br/portal/saude/deciframeoudevorote/files/ministerio/materiais/encontro_nacional/reuniaofaculdades.pd

2011: http://crofsblogs.typepad.com/h5n1/2012/03/brazil-sees-66-drop-in-dengue-cases.html; http://en.mercopress.com/2012/04/25/rio-do-janeiro-admit-a-dengueepidemic-over-50.000-cases-and-12-deaths

Hepatitis A/B (2004-2010): http://www.aids.gov.br/sites/default/files/anexos/publicacao/2011/50073/boletim hepatites2011_pdf 64874.pdf

Meningitis, 2007: http://acritica.uol.com.br/noticias/Dados-Ministerio-Saude-Brasil-Amazonas_0_608939200.html

2009: http://portal.saude.gov.br/portal/arquivos/pdf/nt_meningite_brasil15_03.pdf

2011: http://portal.saude.gov.br/portal/saude/profissional/visualizar texto.cfm?idtxt=37810

2009-2000: http://www.ripsa.org.br/fichasIDB/pdf/2010/FichaD1.16.pdf

Yellow Fever (2007-08): http://portal.saude.gov.br/portal/arquivos/pdf/boletim_svs_febre_amarela_040408.pdf

http://www.cve.saude.sp.gov.br/htm/zoo/FA_INFORME.htm

http://www.medicina.ufmg.br/rmmg/index.php/rmmg/article/viewFile/108/89

http://portal.saude.gov.br/portal/arquivos/pdf/boletim_febre_amarela_09_12_09.pdf

http://portal.saude.gov.br/portal/arquivos/pdf/tabela_1_fa_2010.pdf. 
by increasing their bureaucratic and policy commitment prior to the Global Fund's emergence, the latter nevertheless helped to further deepen health governance at these multiple stakeholder levels while directly contributing to new community-based institutional innovations. Indeed, we found that the Global Fund helped strengthen national bureaucratic commitment to TB while incentivizing cooperation between previously uncooperative health agencies, such as the national AIDS and TB programmes, due mainly to the Global Fund's grant requirement of addressing the TB-HIV/AIDS co-infection problem. At the same time, the Global Fund has helped to further increase inter-governmental cooperation between the $\mathrm{Na}$ tional TB Programme (NTP) and sub-national municipal health agencies as well as between the NTP and nongovernmental organizations (NGOs). Our findings also suggest that the Global Fund's investments have not only helped deepen social mobilization, but it has also had a direct impact on fostering new institutional innovations at the community-level, thus further enhancing local participatory governance.

But as we discuss in the conclusion, it is important to note that the Global Fund has not had as positive of an impact in other nations. In contrast to Brazil, other countries simply do not have the same level of preexisting political and bureaucratic commitment, as well as the rich history of social mobilization in drawing attention to health issues and pressuring the government for policy reform. Consequently, despite the Global Fund's presence, few nations have been able to see as positive of an impact on health governance.

\section{Materials and methods}

In this study, we first conducted an extensive literature review discussing the impact that donor and global financial initiatives have on health governance. This was followed by empirical evidence from an in-depth case study of Brazil, which combined both qualitative and quantitative data from Global Fund grant disbursements to Brazil and $\mathrm{MOH}$ annual expenditures. We selected the case of Brazil for two key reasons: First, to provide a good example of how Global Fund investments can strengthen government and civil societal commitments and capacity to respond to relatively neglected diseases, such as TB, as well as increased coordination and accountability within and between government and civil society. Second, we selected the case of Brazil in order to provide greater knowledge, examples, and lessons about the complexities of health governance at multiple stakeholder levels.

Qualitatively, and as the Methodological Appendix explains, we conducted in-depth interviews with key informants from the Global Fund, national and subnational health officials, medical doctors, academics, and activists. We conducted an iterative methodological approach [35]. Through this approach, researchers conduct the case study analysis during rather than after the collection of data [35]. By simultaneously and repeatedly consulting interview data with case study evidence from different phases of the analysis, we were able to develop and refine our initial research questions, identify causal patterns, devise concepts of health governance based on these patterns, and establish linkages between the data. This was done in order to corroborate our ideas and concepts while providing a more accurately defined case study. And in an effort to provide supportive evidence of our causal claims from multiple empirical sources, also known as the method of triangulation [36], which is useful when there is a limited amount of published findings, the interview data was supported with evidence from printed media, published articles, and reports. This study primarily took place from November 2009 to August 2010, with additional interviews undertaken in 2012.

\section{The impact of external investments on health governance}

The benefits of integrating targeted health programmes into mainstream health system functions has been the subject of a longstanding debate in relation to the organization and financing of health systems focused on increasing access and improving health outcomes [3739]. This debate has too often been fueled by polarized views of protagonists for and against the integration of targeted or vertical programs, arguing the relative merits of each approach [40]. This debate has been recently rekindled due to substantial increases in external investments for immunization programmes by GAVI, and AIDS, tuberculosis and malaria by the Global Fund. However, all too frequently the arguments for or against integration have not been underpinned by robust consistent evidence $[17,41]$.

In the last decade, the major focus of G8 summits in Japan, Italy and Canada has been developing country approaches that foster both health systems strengthening and disease-specific targeted approaches. However, few studies have explored how and to what extent the new external financing and organisational arrangements provided by global financial initiatives, such as the Global Fund and GAVI, have influenced the governance of vertical health systems and horizontal programmes in countries receiving financing from these agencies [17].

This debate and lack of evidence highlights the importance of our research question: that is, how and to what extent does the Global Fund strengthen vertical and horizontal health governance approaches to disease? How do these external investments influence integration of vertical disease programmes, such as TB, into health systems and horizontal approaches, such as community 
participation through decentralisation processes, to addressing diseases? As the case of Brazil will illustrate, investments from the Global Fund can strengthen the integration of vertical programmes into health systems while strengthening community participation.

With regards to theory, we analyse the literature's discussion of the impact that external investors, such as donors and global financial initiatives, have on health governance. While a number of recent studies have examined how political stewardship, accountability, intergovernmental accountability and cooperation, decentralisation, civic ownership, and participation affects the implementation of health policy $[19,26,42,43]$, these studies limit their analysis to governance processes within governments, failing to address the impact that donors and global financial initiatives have on this process. With the exception of a recent study exploring how the Global Fund's efforts to foster community ownership and participation have facilitated more inclusive policy development and implementation [5], little has been written on this process. Indeed, the few studies that examine donor and global financial initiatives' impact on health governance have focused on government and civil societal inclusion in the grant application process, either through the creation of formal decision-making mechanisms, such as the Global Fund's Country Coordinating Mechanisms, or as explicit requirements for NGOs and other civic organisations seeking funding [44]; in essence, these are approaches which aim to empower civil society and build their trust and cooperation with the national government $[4,45]$.

Other studies conducted by the World Bank and others exploring donor and global financial initiative impacts on health governance have emphasised their concerns with organisational and absorptive capacity to prudently manage external funds in a timely manner $[2,7,10,12]$. To strengthen local organisational and absorptive capacity, donors and global financial initiatives have simultaneously funded health systems and disease specific targeted programmes [21-24,46], as exemplified by the Global Fund, which by 2010 had approximately one-third of its approved investments in health systems strengthening, such as human resources (e.g., employing doctors, nurses, healthcare workers and workforce training), health information systems, health financing, leadership and governance [11,33].

When analyzed from a political science perspective, however, these studies provide a limited view of global financial initiatives' impact on health governance, as they do not address broader issues that are important for ensuring effective policy implementation, such as: (i) the impact global financial initiatives have on domestic government leadership and policy commitment - which is a key theme in the literature addressing the impact of donors on domestic AIDS politics and policy [14,47]; (ii) how global financial initiatives increase the interests of political and bureaucratic leaders in favour of addressing relatively neglected diseases, such as TB; (iii) how global financial initiatives' support affects intra-bureaucratic relationships to promote multi-sectoral partnerships; and (iv) the extent to which these financial initiatives motivate national agencies to engage with state and municipal agencies as well as civil society when addressing health issues. Furthermore, while studies dealing with national-level processes have provided useful insight into the influence of widening stakeholder involvement on diversity and accountability in policy-making $[4,45]$, they have not explored the way in which global financial initiatives have generated incentives to mobilise civil society, deepen their interaction with political and bureaucratic elite, and to promote greater transparency and accountability.

\section{Brazil}

In contrast to the response to HIV/AIDS, when the Brazilian government created a national AIDS program and new prevention and treatment initiatives by the late1980s, the government did not respond in a similar manner to TB. Brazil's response to its TB epidemic was incongruous with the severity of the problem, which worsened as a result of increased urbanization, poverty, and HIV co-infection [48]. Throughout the 1980s and 1990s, moreover, the NTP did not have sufficient funding, both because TB was not perceived as an urgent public health threat and because of the economic recession, which impaired funding for most disease programmes $[48,49]$. The NTP, which was decentralised in the 1990s and consequently weakened [48,49], only began to receive political attention when new sources of funding became available.

Brazil first requested Global Fund financing in 2004 (Round 4 financing). Despite indicating a clear need for resources, Brazil's request was initially declined by the Global Fund Technical Review Panel (TRP), mainly because of the Country Coordinating Mechanism's (CCM) inadequate representation of civil society on the grant application [Global Fund official, personal communication, October 1 and 29, 2009; 48]. Nevertheless, in 2005 the request for Round 5 financing was recommended for approval by the TRP, as the revised CCM membership now included individuals affected by TB, other members from civil society as well as mechanisms ensuring the latter's continued participation in policy-making [Global Fund official, personal communication, October 1 and 29, 2009; E. Santos-Filho, personal communication, June 30, 2006].

As Table 2 illustrates, US\$23 million was approved by the Global Fund Board over five-years for the project "Strengthening of the TB-DOTS Strategy in 10 Metropolitan 
Table 2 Global Fund Grants

\begin{tabular}{llll}
\hline TB - Round $\mathbf{5}$ (US\$ millions) & & & \\
\hline Principle Recipients & Total Funding Requested & Approved Maximum & Total Funds Disbursed: \\
FAP/FIOTEC & $\$ 23,021,005.00$ & $\$ 23,021,005.00$ & $\$ 15,194,557.00$ \\
Total: & $\$ 23,021,005.00$ & $\$ 23,021,005.00$ & $\$ 15,194,557.00$ \\
\hline
\end{tabular}

Source: The Global Fund to Fight AIDS, TB, and Malaria, 2009.

Areas and in the City of Manaus in Brazil," for two principal recipients (PRs): the Foundation for Scientific and Technological Development in Health (Fundação para o Desenvolvimento Científico e Tecnológico em Saúde FIOTEC) and the Ataulpho de Paiva Foundation (Fundação Ataulpho de Paiva - FAP). The overall objective of the five-year grant was to expand DOTS coverage, increase social mobilization, information and awareness, reduce stigma, and to establish joint programs with the National AIDS Program [50]. By 2009, the PRs had received approximately $\$ 16$ million of the approved funds and are scheduled to receive the remaining funds.

Similar to what occurred with World Bank funding and HIV/AIDS policy in the early-1990s, the emergence of the Global Fund positively influenced and further accelerated the government's preexisting commitment to responding to TB $[48,49]$. Prior to the Global Fund's emergence in the 1990s, the rise of international criticisms and pressures for a stronger response to TB from international organizations, e.g., the World Health Organization (WHO), and the media motivated the $\mathrm{MOH}$ to strengthen its bureaucratic and policy commitment to TB $[48,51]$. The $\mathrm{MOH}$ was essentially embarrassed with the government's biased response to other communicable diseases, such as HIV/AIDS, and saw a renewed commitment to re-building the NTP as a way to rejuvenate the government's reputation [48]. Moreover, by the early-1990s the number of TB cases had multiplied, thus making it impossible to ignore the situation. In response, in 1998 the $\mathrm{MOH}$ worked with the Congress to re-centralize the NTP's policy responsibilities [48,51], such as monitoring TB cases, providing technical policy advice and guidelines, and funding medications $[48,52,53]$. The $\mathrm{MOH}$ also gradually increased its allocation of funding to the NTP to support these initiatives $[48,52,53]$.

Nevertheless scholars soon began to identify the weaknesses of the NTP in effectively delivering prevention and treatment services $[49,54]$. Moreover, the NTP was not fully committed to working with local health departments and clinics [48]. Thus, while there was an increase in attention and resources for TB, national political and bureaucratic commitment to policy implementation was somewhat weak [48]. This was mainly due to the lack of sufficient funding, as well as motivation and accountability for the NTP's actions.
The emergence of Global Fund support by 2006 nevertheless helped to strengthen the MOH's pre-existing commitment to TB control [49]; D. Barreira, personal communication, October 20, 2009; F. Moherdaui, personal communication, June 16, 2006; V. Terto, personal communication, May 22, 2012; E. Santos-Filho, personal communication, May 23, 2012]. The need for additional financial resources as well as the government's newfound commitment to working with civil society as a condition for Global Fund support compelled the $\mathrm{MOH}$ to increase its commitment to the implementation of policies aimed at strengthening TB control [F. Moherdaui, personal communication, June 16, 2006; M. Dalcolmo, personal communication, October 20, 2006; B. Durovni, personal communication, July 7, 2006; V. Terto, personal communication, May 22, 2012; R. Burgos Filho, personal communication, May 23, 2012; Table 3]. Additional funding from the Global Fund also provided the operational freedom and capacity for the NTP to appoint new staff (mainly from the national AIDS programme) while using Global Fund money to hire short-term consultants to work on the implementation of policies [C. Basilia, personal communication, November 15, 2009; M. Sanchez, personal communication, July 2, 2011; E. Santos-Filho, personal communication, May 23, 2012; R. Burgos Filho, personal communication, May 23, 2012]. Furthermore, in addition to further incentivizing $\mathrm{MOH}$ commitment to the NTP, Global Fund support motivated the President and the $\mathrm{MOH}$ to publicly discuss the NTP and its policies, at levels that were never before seen [48,55]; E. Santos-Filho, personal communication, June 30, 2006 and May 23, 2012; V. Terto, personal communication, May 22, 2012; R. Burgos Filho, personal communication, May 23, 2012].

In Brazil, the Global Fund emerged at a time of bureaucratic discord within the $\mathrm{MOH}$, with tensions between the AIDS and TB programmes dating back to the 1990s, due mainly to the biased support that the National AIDS Programme received [49]; A. Kritski, personal communication, July 20, 2006; M. Dalcolmo,

\section{Table 3 Brazil: available funding for the National TB} Program

\$US (millions) 2000200120022003200420052006200720082009

$\begin{array}{llllllllll}9.3 & 6.3 & 5.2 & 13.6 & 27.4 & 29.7 & 44.3 & 58.8 & 71.6 & 74\end{array}$

Source: Ministry of Health, 2010. 
personal communication, October 20, 2006; V. Terto, personal communication, May 22, 2012]. This conflict was sparked by the fact that the NTP had enjoyed strong financial support and visibility in the preceding decades [48]; M. Dalcolmo, personal communication, October 20, 2006; 49]. However, because part of the Global Fund's grant money was to be used for addressing the rising TB-HIV/AIDS co-infection problem, TB and HIV/AIDS officials were motivated to strengthen their work together [Global Fund official, personal communication, October 1 and 29, 2009; D. Barreira, personal communication, October 20, 2009; Brazilian NTP official, personal communication, November 5, 2009; F. Moherdaui, personal communication, June 16, 2006; E. Santos-Filho, personal communication, May 23, 2012; R. Burgos Filho, personal communication, May 23, 2012]. Indeed, the Global Fund grant required that TB and AIDS officials develop new policy initiatives and awareness campaigns, such as conferences, in turn helping make the health problem more visible [ibid; 49]; G. Gerhardt, personal communication, July 19, 2006; F. Moherdaui, personal communication, June 16, 2006; V. Terto, personal communication, May 22, 2012; E. Santos-Filho, personal communication, May 23, 2012].

Coinciding with negotiations with the Global Fund to finalise contracts to receive funding, in 2005 the NTP created a special division, the Coordenador Adjunto, Programa Nacional de Controle da Tuberculose (Adjunct Coordinator of the National Tuberculosis Program), to strengthen its partnership with the National AIDS Programme [F. Moherdaui, personal communication, June 16, 2006; 50]. This was aided by the fact that the Adjunct Coordinator, Fabio Moherdaui, as well as the director of the NTP, Draurio Barreira, had previously worked in the National AIDS Programme and had extensive networks [V. Terto, personal communication, May 22, 2012; E. Santos-Filho, personal communication, May 23, 2012], experience, and a strong commitment to creating a collaborative partnership with the National AIDS Program [D. Barreira, personal communication, October 20, 2009; F. Moherdaui, personal communication, June 16, 2006; E. Santos-Filho, personal communication, May 23, 2012].

During this period, social mobilisation was also visibly profound and motivated by Global Fund financing for civil society. While previously no NGOs had been formally established to support TB control, in 2003 activists from the state of Rio formed the Fórum Estadual das ONGs na luta contra a Tuberculose no Rio de Janeiro (Forum of State NGOs against Tuberculosis in Rio de Janeiro); São Paulo followed suit with the creation of its own Fórum that same year, as well as the Rede para $o$ Controle Social da TB no Estado de São Paulo (Tuberculosis Social Control Network of São Paulo) in 2005.
These Fórums were comprised of community-based organizations, the church, businesses, sex worker organizations, feminist groups, as well as AIDS NGOs [48,56]. Activists and researchers nevertheless emphasize that the Fórums were not influential during this period in pressuring the NTP to strengthen its response to TB (C. Basilia, personal communication, October 17, 2006, and November 15,$2009 ; 48,56]$. Indeed others have characterized the NTP's relationship with the Fórums during this period as tenuous and superficial, a relationship that was created only to attract international financial support rather than to effectively include and increase the Fórums' policy ideas and influence within the NTP [56]. Nevertheless, the Fór$u m s^{\prime}$ size grew and were energized as the Global Fundsupported TB programmes rolled out - though it is important to note that the Fórums were never the principle recipients of Global Fund support [C. Basilia, personal communication, October 17, 2006, and November 15, 2009; 48,49]. The Fórums quickly began to mobilise in order to engage in the design and implementation of new policies [49]; C. Basilia, personal communication, November 15, 2009]. Because most of the policies that AIDS NGOs had pressured the government for, such as universal access to antiretroviral treatment (ARV), had been implemented by the late-1990s [32], there were fewer opportunities for AIDS NGOs to justify and receive funding to mobilize and work on these policy issues [57]. This prompted a number of relatively unemployed AIDS NGOs to join the Fórums $[57,58]$, with the latter growing in size and in other cities [C. Basilia, personal communication, November 15, 2009; 48].

In addition to forming a closer relationship with the NTP [M. Sanchez, personal communication, July 2, 2011; Figure 2; Table 4], the Fórums also drew greater attention to the HIV-TB co-infection problem, mainly through the media, workshops, and conferences [56]. Fórums have also worked closely with municipal and state health secretariats to organize national meetings to discuss policy issues, such as the Encontro Comunitário das ONGs na Luta contra a Tuberculose no Estado do Rio de Janeiro (Community Meeting of NGOs in the Fight Against Tuberculosis in the State of Rio de Janeiro).

Global Fund support has also helped strengthen intergovernmental cooperation between the NTP and subnational governments - which is important, especially given the financial and administrative challenges associated with the devolution of health policy responsibilities through the Sistema Único de Saúde (SUS), the decentralised universal healthcare system [59]. Moreover, while the municipalities are responsible for collecting revenue and expenditures for healthcare [60], cooperation is important as the states and municipalities are reliant on the $\mathrm{MOH}$ for financial assistance through discretionary fiscal transfers [60,61], which are often 


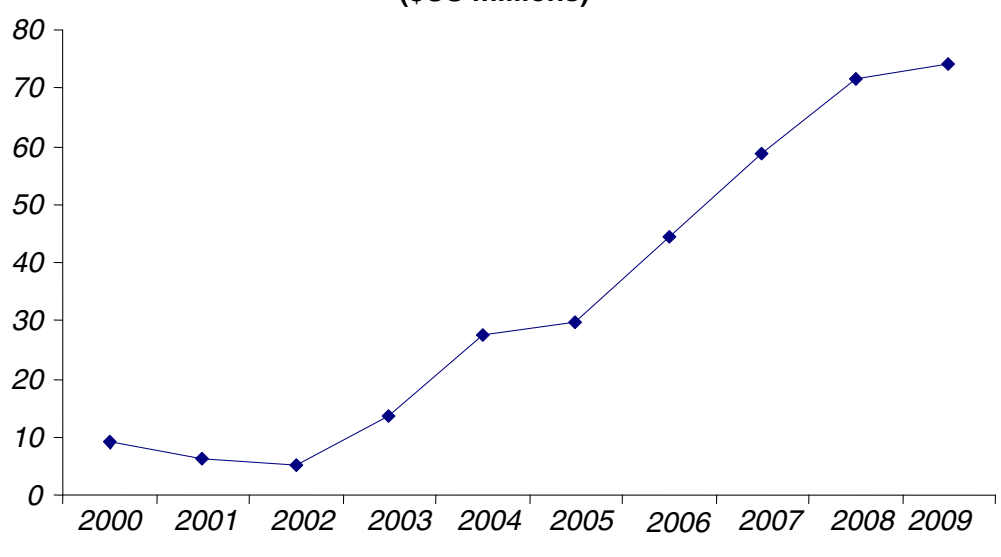

Source: Ministry of Health, Brazil, 2009

Figure 2 Brazil: National TB Program Funding available for activities with Civil Society.

conditional, based on the amount of responsibilities municipalities have agreed to take in providing healthcare services [62]. While inter-governmental cooperation did exist prior to the Global Fund's establishment, beginning in 2002 to 2003 [E. Santos-Filho, personal communication, May 23, 2012], the NTP was not as committed to meeting with subnational governments. Because of the Global Fund's periodic assessment of CCM performance for grant renewal, the NTP had incentives to further increase its preexisting commitment to cooperating and meeting with state and municipal health departments [D. Barreira, personal communication, October 20, 2009; M. Sanchez, personal communication, July 2, 2011; E. Santos-Filho, personal communication, May 23, 2012]. The NTP has intensified its commitment to working closely with the states and municipalities in order to implement Global Fund financed projects [63]; D. Barreira, personal communication, October 20, 2009; M. Sanchez, personal communication, July 2, 2011; E. Santos-Filho, personal communication, May 23, 2012] as well as to provide adequate financial and technical assistance for FAP and FIOTEC's work and DOTS implementation [64].

In addition, in order to ensure that principle recipients (PR) of grants have adequate support and work effectively, the NTP provides consistent technical support and site visits to discuss and evaluate policy implementation as well as needs [D. Barreira, personal communication, October 20, 2009; Brazilian NTP official, personal communication, November 5, 2009; M. Sanchez, personal

Table 4 Brazil: National TB Program Funding available for activities with Civil Society

\begin{tabular}{lllll}
\hline Reais \$ (millions) & 2007 & 2008 & 2009 & 2010 \\
& $536,492.00$ & $726,718.00$ & $1,501,819.00$ & $1,162,000.00$
\end{tabular}

Source: Ministry of Health, Brazil, 2008 \& 2011. communication, July 2, 2011; E. Santos-Filho, personal communication, May 23, 2012]. This technical support also helps to increase PR accountability to the NTP [M. Sanchez, personal communication, July 2, 2011]. The NTP also regularly interacts with municipal health secretaries in Rio and other cities to ensure that it has adequate technical support [ibid; V. Gallesi, personal communication, October 13, 2009; M. Sanchez, personal communication, July 2, 2011; E. Santos-Filho, personal communication, May 23, 2012]. Because the NTP is accountable, through the CCM, to the Global Fund for the FAP and FIOTEC's performance, the programme has further incentives to work closely with these institutions and the municipalities in order to ensure policy success [D. Barreira, personal communication, October 20, 2009; Brazilian NTP official, personal communication, November 5, 2009; V. Gallesi, personal communication, October 13, 2009; M. Sanchez, personal communication, July 2, 2011].

It is also important to note that the Global Fund has had a direct impact on health governance at the community-level, fostering a greater commitment to civic mobilization, empowerment, and accountability [V. Terto, personal communication, May 22, 2012; M. Sanchez, personal communication, July 2, 2011; E. Santos-Filho, personal communication, May 23, 2012]. In order to ensure that the PR's work effectively, in 2006 members of civil society in Rio and São Paulo, in conjunction with municipal health secretariats and the NTP, created Comitês Metropolitanos (Metropolitan Committees), which are independent entities, not financed by the Global Fund. Modeled after the 1988 constitutionally-mandated municipal health councils, these Comitês are public participatory institutions. AIDS NGOs, Fórum members, municipal health officials, people affected by TB, the church, and staff from 
the MOH's Global Fund supported programme periodically meet to closely monitor the provision of Global Fund financing, review all aspects of Global Fund programmes, grant performance, impact, discussions for creating new funding proposals and potential PRs, as well as networking $[63,65]$; D. Barreira, personal communication, October 20, 2009; V. Gallesi, personal communication, October 13, 2009; L. Brilhante, personal communication, July 6, 2010; J. Matsudo, personal communication, August 17, 2010; A. Alegria de Almeida, personal communication, July 1, 2010; N. Faraone, personal communication, June 4, 2010; M. Sanchez, personal communication, July 2, 2011; E. Santos-Filho, personal communication, May 23, 2012].

Though initially created in Rio, Comitês have also emerged in eight other cities, namely Belo Horizonte, Fortaleza, Manaus, Porto Alegre, Recife, Salvador, São Luís, and São Paulo. Because of the high incidence of the TB-HIV co-infection, São Paulo has created two Comitês, which are well known for exhibiting a very strong commitment to civic participation [V. Gallesi, personal communication, October 13, 2009; N. Faraone, personal communication, June 4, 2010; A. Alegria de Almeida, personal communication, July 1, 2010].

These Comitês have provided even further opportunity for the NTP to work closely with civil society and local health departments [L. Brilhante, personal communication, July 6, 2010; J. Matsudo, personal communication, August 17, 2010; A. Alegria de Almeida, personal communication, July 1, 2010; N. Faraone, personal communication, June 4, 2010; V. Gallesi, personal communication, October 13, 2009; D. Barreira, personal communication, October 20, 2009; M. Sanchez, personal communication, July 2, 2011; E. Santos-Filho, personal communication, May 23, 2012]. The director of the NTP as well as MOH officials working on the Global Fund grant frequently attend Comitês meetings [ibid]; this demonstrates strong government support as well as oversight in the grant implementation process [66]; Brazilian NTP official, personal communication, November 5, 2009; D. Barreira, personal communication, October 20, 2009; V. Gallesi, personal communication, October 13, 2009; N. Faraone, personal communication, June 4, 2010; M. Sanchez, personal communication, July 2, 2011]. The Comitês also benefited from the direct support of the former Minister of Health, José Temporão, who attended meetings on a number of occasions [67].

The creation of municipal Comitês provides further evidence of the ongoing drive in Brazil to improve transparency and participatory governance for health. In essence, this community-level institution-building response is an extension of civil society's historic commitment to ensuring "social control" for health, the origins of which dates back to the 1960s with the movimento sanitarista [68].
This movement was committed to pressuring the government to provide universal healthcare as a constitutionallyguaranteed human right, socially controlled through the decentralization process [68].

Global Fund support has therefore had a positive impact on health governance in Brazil, engendering a stronger commitment to increasing engagement and participation at all levels of government and civil society [V. Terto, personal communication, May 22, 2012; E. Santos-Filho, personal communication, May 23, 2012]. Global Fund support has also provided new opportunities to deepen civic participation by directly involving TB victims and their supporters on the CCM. An analysis of recent budgetary allocations (Figures 1 and 3) suggests that civil society, including affected communities, has benefited from Global Fund support.

\section{Discussion}

Our findings suggest that at the intra-governmental level, Global Fund financing has helped strengthen the increased engagement of the $\mathrm{MOH}$ in $\mathrm{TB}$ control, while fostering stronger cooperation between the national AIDS and TB programmes. At the inter-governmental level, Global Fund financing, its inclusiveness principle and accountability framework have also provided incentives for the NTP to strengthen its partnership with sub-national health departments and civil society. At the communitylevel, Global Fund support has also helped to deepen civic mobilization through the Fórums, expand civic participation in decision making, improve transparency and accountability, while fostering community-level institutionbuilding with the creation of the Comitês Metropolitanos. These institutions have provided venues for strengthening collaboration between communities, the NTP, and local health officials.

However, it is important to note that the Global Fund was limited in its direct contribution to the creation of multiple levels of health governance in Brazil. While the Global Fund did directly contribute to the creation of community-based accountability institutions (i.e., the Comitês Metropolitanos), it did not instigate national government interest and commitment to responding to TB. Rather, Global Fund financing complemented and further strengthened pre-existing efforts to address TB at the national government level (E. Santos-Filho, personal communication, May 23, 2012).

Furthermore, it is important to note that it was not the simultaneous combination of Global Fund money and civil societal pressures that gave the $\mathrm{MOH}$ the confidence and incentives needed to strengthen its response to TB. While Global Fund financial support was necessary, civil society's pressures for policy reform through the Fórums were present prior to the Global Fund's emergence; however, these civic pressures did not have 


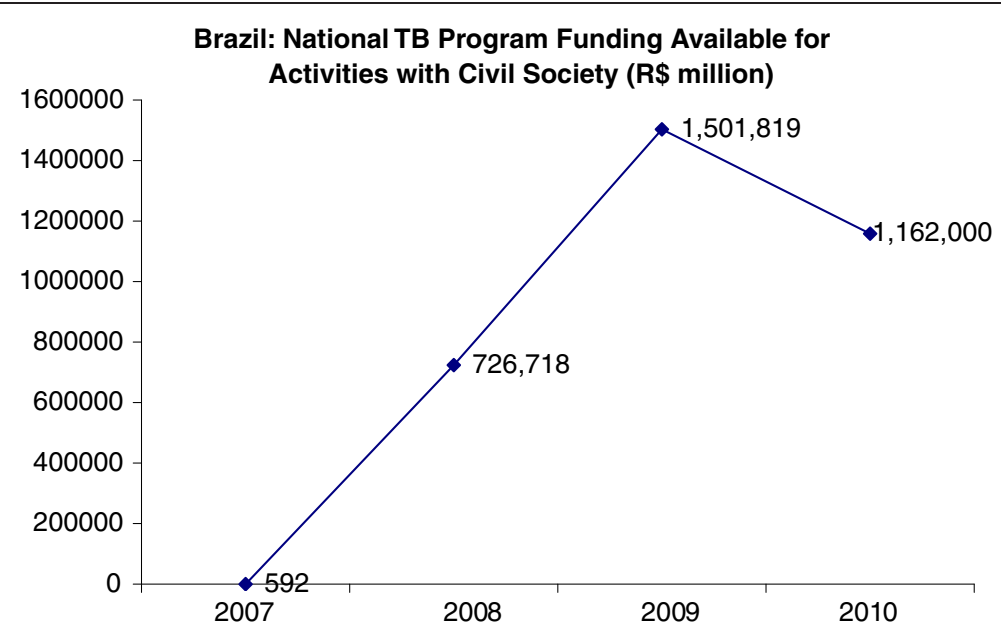

Source: Ministry of Health, Brazil, 2008 \& 2009

Figure 3 Brazil: Available Funding for the National TB Program.

any influence on strengthening the MOH's commitment to policy reform $[17,48,56]$. The influence of the Fórums and civil society on strengthening the MOH's commitment to policy reform only seemed to emerge after the Global Fund mandated civil society's inclusion onto the CCMs and PRs. Therefore it seems that Global Fund support and its grant conditionalities, not civil societal pressures, were the most important factors leading to a further increase in national government responses to TB.

Several key lessons emerge from analyzing the Global Fund's impact on health governance in Brazil. First, while empirical research has explored health governance and policy implementation in developing countries $[26,36,42,65,69]$, as well as its impact on stake-holder inclusion, transparency, and financial management $[4,7,10,12,45]$, few have examined the impact that global financial initiatives have on multiple levels of health governance. The case of Brazil shows that a more nuanced analysis of health governance at multiple levels provides a more robust demonstration of the extent to which global financial initiatives further compel national politicians, bureaucrats, and civil society to respond to relatively neglected diseases, while building new institutions and accountability mechanisms at the community level.

Second, this case study suggests that Global Fund support can foster participatory approaches to addressing relatively neglected diseases, such as $\mathrm{TB}$, at levels that are similar to country responses to HIV/AIDS $[3,69]$.

Third, the availability of new funding also increased the attention and support of previously marginalized national TB officials, motivating them to work in a more collaborative manner with national AIDS officials and civil society in response to TB. Thus by funding the
NTP to address the TB/HIV co-infection problem, the Global Fund has also helped catalyse and strengthen inter-agency cooperation for a more aggressive response to $\mathrm{TB}$.

Fourth, an interesting new finding relates to institutionbuilding at the community-level. Earlier studies on health governance have explored the construction of effective national-level institutions, such as national AIDS programmes and commissions [14,70]. In Brazil, financing from the Global Fund amidst the backdrop of pre-existing political and constitutional commitments to social control over health policy can motivate local communities to work with local governments in creating new community-based institutions, such as the Comitês Metropolitanos. These community-based institutions are created with the expressed intent of deepening civic engagement, accountability, and social control. Whereas national AIDS commissions have served this purpose at the national-level, Comitês have shifted governance and engagement to the community-level. While Brazil may be unusual in this regard, given its rich history of social control for health, future work will need to explore the extent to which communities in other nations are building new institutions to ensure the effective use of international funding.

Given the financial crisis faced by the Global Fund and its policy direction to withdraw from middle-income countries, the durability of the Global Fund's positive effects in Brazil are in question. Furthermore, after the Global Fund denied Round 9 funding to the NTP in November 2009 [71], on the grounds that the government had sufficient revenue to finance its TB programmes, there have been concerns that the NTP and civil society will remain committed to working together in implementing policies once Global Fund financing ceases. However, so far it seems that sustaining this commitment 
and partnership between the NTP and civil society will occur, and for two reasons: first, the government and civil society's preexisting commitment to responding to $\mathrm{TB}$, and second, the Global Fund's impact in further strengthening $\mathrm{MOH}$ commitments to policy implementation, as well as creating new venues for civil society to further strengthen its mobilization and monitoring capabilities, such as the Comitês Metropolitanos, which continue to thrive [E. Santos-Filho, personal communication, May 23, 2012]. Notwithstanding the inability to obtain further Global Fund support, recent interviews with activists and government officials suggests that the government and civil society is still equally if not more committed to working together in order to curtail the spread of TB [E. SantosFilho, personal communication, May 23, 2012; V. Terto, personal communication, May 22, 2012; R. Burgos Filho, personal communication, May 23, 2012; M. Sanchez, personal communication, July 2, 2011; D. Barreira, personal communication, June 10, 2011; P. Werlang, personal communication, August 1, 2011].

Nevertheless, it is important to note that the Global Fund's impact in other nations has not been as positive. In China, for instance, research finds that the provision of Global Fund grants for AIDS prevention and treatment in 2004 did not lead to inter-bureaucratic coordination, increased coordination between the $\mathrm{MOH}$ and the states, as well as the creation of new community-based institutions [72]. While the Global Fund's presence did increase civil societal participation on CCMs, many NGOs were controlled by the $\mathrm{MOH}$, while selection processes for CCM participation were politically manipulated until very recently [73]. In contrast to Brazil, the absence of a rich history of social movements and participation in health policy-making and political accountability for policy implementation complicated the Global Fund's ability to deepen health governance in China.

Other countries have experienced similar challenges [74]. In the Ukraine, despite being a PR for Global Fund assistance, the $\mathrm{MOH}$ did not have the political commitment needed to manage the grant money effectively [74]. Consequently, when the Global Fund recommended that the $\mathrm{MOH}$ no longer be a PR, $\mathrm{MOH}$ officials objected and negatively reacted by withdrawing their support for the Global Fund's work with AIDS NGOs [74]. This revealed the Ukrainian MOH's self interest and unwillingness to reform its managerial funding procedures in order to be re-considered as a PR, while lacking the commitment needed to ensure that AIDS NGOs' needs were met. Similarly, in Myanmar, during the mid-2000s the $\mathrm{MOH}$ was not committed to helping AIDS and TB NGOs work with Global Fund staff, such as denying Global Fund staff entry visas to visit programme sites [74]. This revealed the government's lack of commitment in facilitating the PR recipients' work, which in turn suggested the MOH's apathy in ensuring civil societal needs.

Finally, in other countries, such as Cambodia and the Cameroon, NGOs have not had the organizational, technical, financial managerial, and communication skills needed to work effectively with health officials and to hold them accountable [38]. Moreover, NGOs on CCMs in these nations have little experience in mobilizing and organizing committees outside of the CCM in order to hold it and the Global Fund accountable [38]. In this context, and in sharp contrast to Brazil, the Global Fund's influence in deepening health governance and accountability has been rather limited.

Because of these challenging environments, others have viewed the Global Fund's investments as causing more harm than good. In addition to providing new opportunities for government corruption as a result of CCM mandates, as seen in China, others have been critical of the consequences associated with the Global Fund's decision to suddenly discontinue grants, often due to allegations of corruption and grant mismanagement in recipient nations [75], as well as the Global Fund's lack of transparency in decision-making [74,75]. In some cases the permanent or temporary cancellation of grants has delayed the work of NGOs working on prevention and treatment programmes [75]. In Indonesia, for example, several healthcare workers resigned from positions with PRs because of the non-payment of salaries and financial uncertainty [75]. Most of these criticisms of the Global Fund can also be attributed to the limitations in governments' commitment to closely monitoring PRs and CCMs, government commitment to transparency, eradicating corruption, and ensuring that PRs and CCMs can work freely with Global Fund staff.

What this therefore suggests is that the generalizability of our findings in Brazil may be limited to the case of Brazil; this gives the impression, moreover, that Brazil is sui generis in terms of having the propitious, preexisting political commitment and history of effective social health movement mobilization and accountability [73]. These preexisting conditions have facilitated the Global Fund's positive affects at multiple levels of health governance. Future research will need to examine if other countries have similar preexisting conditions and if not, what else the Global Fund can do to help strengthen this process.

We acknowledge that there are some limitations to our study. First, there are no earlier studies on the subject, thus scant empirical evidence to draw on. Our study addresses this problem by conducting extensive interviews and triangulating our interview data with other types of empirical evidence, while engaging in an iterative methodological process. Second, the argument could be made that electoral incentives as well as the historic legacy of progressive 
government commitment to combating epidemics and social control would have eventually led to an aggressive response to TB. While we did not address these issues, to our knowledge, no national- or community-level politician has ever campaigned on the TB issue, while though present, a very limited national and community-based response occurred prior to the Global Fund's emergence $[48,56]$. Third, the influence of other lenders, donors, and global financial initiatives needs to be taken into account when reaching conclusions. For example, while the World Bank has been helpful in stimulating national- and community-based responses to AIDS [8,32], while the USAID and Management Sciences for Health (MSH) has provided funding for TB prior to the Global Fund in order to improve the provision of drug treatment through DOTS [48], neither was specifically focused on strengthening health governance at multiple stakeholder levels. To our knowledge, aside from the Global Fund, no other donor or global financial initiative has focused on this issue.

\section{Conclusion}

This study has emphasized the potentially positive affects that global financial initiatives have on strengthening multiple levels of health governance. Considering the worldrenowned success of the Brazilian government's response to AIDS and its progressive commitment to universal healthcare, it is interesting that Brazil approached the Global Fund for help in its response to TB. Doing so nevertheless revealed that in the absence of external financial support and accountability to the Global Fund, own its own the $\mathrm{MOH}$ may not have responded as aggressively to $\mathrm{TB}$, nor would civil society have had a reason to become more innovative in creating new accountability institutions at the community level.

While we have built on the work of recent scholars emphasizing the need to expand our concepts and analysis of health governance to the governmental and community-level [25,76], our work highlights the importance of examining how global financial initiatives can further strengthen this process. Indeed, while the MOH's commitments to responding to TB was present prior to the Global Fund, and while social movements, such as the Forrums, had emerged by 2003, we found that the Global Fund's investments in Brazil helped to further strengthen health governance within government and civil society. More specifically, the provision of additional funding, when combined with the Global Fund's mandate that the $\mathrm{MOH}$ address the TB-HIV/AIDS coinfection problem and work closely with civil society, deepened health governance at the intra- and intergovernmental level, while leading to new communitybased institutional innovations.

Findings from Brazil further suggest that the Global Fund's success in strengthening health governance at multiple levels is ultimately determined by antecedent historical political and social conditions. Global Fund staff and other international health financiers need to better understand the political and social context of the nations that they are working in, rather than mechanically focusing on the management of grant finances. Context matters: that is, undertaking contextual and health system analysis is critical to ensuring desired health policy outcomes at a time of increasingly scarce international resources for health.

\section{Appendix}

\section{Methodological appendix - interviews}

The individuals interviewed for this study were chosen from officials working in the Global Fund to Fight AIDS, Tuberculosis, and Malaria, the Brazilian National TB Programme (NTP), municipal tuberculosis officials, members of civil society participating in the Fórums, Comitês Metropolitanos, as well as individuals not working in the TB sector, such as AIDS NGO leaders, activists, national AIDS officials, and academics. Extending our interviews to the non-TB sector provided a balanced, unbiased view of the issues that we were interested in. Those Global Fund individuals chosen to be interviewed were selected based on their direct participation in Global Fund support to Brazil and policy formulation at the Global Fund. Those senior officials interviewed at the Global Fund asked to remain anonymous. Two interviews were conducted in October 1, 2009, and October 29, 2009. In Brazil, national and municipal tuberculosis program officials were selected based on their leadership in implementing TB policy, working with the Global Fund (mainly national officials) as well as the PRs (Principal Recipients) and Comitês implementing Global Fund policy. In addition, members of the Comitês in several cities were interviewed because of their experience working with the NTP and municipal health officials. Finally, those individuals not working in the TB sector were chosen for their knowledge of the TB sector, the NTP's interaction with the Global Fund, and personal impressions of the Global Fund's impact on health governance in Brazil. None of those interviewed for this study were chosen for their a-prior policy views and beliefs, thus allowing us to avoid the usage of biased interview data.

With regards to NTP officials, the following individuals were interviewed: the director of the NTP, Draurio Barreira, October 20, 2009 and June 10, 2011 (30 minute phone interview); Patricia Werlang, NTP official, August 1, 2011 (email survey); a senior official within the NTP working on the Global Fund grant, November 5, 2009 (30 minute phone interview); and Fabio Moherdaui, NTP, June 16, 2006. With regards to municipal health officials, Vera Gallesi, coordinator of the São Paulo state TB program, October 13, 2009 (by phone); Margaret 
Dalcolmo, Reference Center for Tuberculosis, Rio de Janeiro, October 20, 2006; Germano Gerhardt, President, Fundação Ataulpho de Paiva, Rio de Janeiro, July 19, 2006; Bettina Dorovni, director of the division of AIDS, TB, and Colera, municipal department of health, Rio de Janeiro, July 7, 2006 (by phone).

Members of civil society and activists included: Afranio Kritski, Universidade Federal do Rio de Janeiro, July 20, 2006; Carlos Basilia, director, Fórum Estadual das ONGs na Luta contra a Tuberculose no Rio de Janeiro, November 15, 2009 and October 17, 2006 (phone interview); Ezio T. Santos-Filho, Vice President, PellaVida NGO, Rio de Janeiro, June 30, 2006; members of the Global Fund Comitês Metropolitanos included: Nadja Faraone, São Paulo, June 4, 2010 (by phone); Joyce Matsudo, Manaus, Amazonia, August 17, 2010 (email survey); Laíze Brilhante, Recífe, July 6, 2010 (email survey); Ana Cristina Alegria de Almeida, Costa da Mata Atlantica, São Paulo, July 1, 2010 (email survey).

Those non-TB individuals that were interviewed included AIDS NGO leaders, activists, national AIDS officials and university professors: Veriano Terto, Executive Director of ABIA, Rio de Janeiro, May 22, 2012 (30 minute phone interview); Ezio T. Santos-Filho, former Vice President of PellaVida AIDS NGO, Rio de Janeiro, currently PhD Candidate, Medical School, Federal University of Rio de Janeiro, May 23, 2012 (30 minute phone interview); Ruy Borgos Filho, Director, National AIDS Program, Brasilia, May 23, 2012 (30 minute phone interview); and Mauro Sanchez, Adjunct Assistant Professor, University of Brasilia, Brasilia, July 2, 2011 (30 minute phone interview).

\section{Competing interests}

The authors have no competing interests to declare.

\section{Ackowledgements}

We wish to acknoweldge $\mathrm{KH}$ for his research assistance. No funding was obtained for this study.

\section{Author details}

${ }^{1}$ Department of Public Policy \& Administration, Rutgers University, 401 Cooper Street, Camden, NJ, USA. ${ }^{2}$ International Health Management, Imperial College Business School and Faculty of Medicine, Imperial College London, Exhibition Road, SW7 2AZ, London, UK.

\section{Authors' contributions}

EG and RA are the primary authors of this study, having devised the theoretical and empirical analysis. All authors read and approved the final manuscript

Received: 27 October 2011 Accepted: 16 July 2012

Published: 16 July 2012

\section{References}

1. Lu C, Schneider M, Gubbins P, Leach-Kemon K, Jamison D, Murray C: Public financing of health in developing nations: a cross-national systematic analysis. Lancet 2010, 10:1-13.

2. Balabanova D, McKee M, Mills A, Walt G, Haines A: What can global health institutions do to help strengthen health systems in low income countries? Health Research Policy and Systems 2010, 22:1-11.
3. Sridhar D, Gómez EJ: Comparative assessment of health financing in Brazil, Russia, and India: What role does the international community play? Health Policy \& Planning 2010, 26:12-24.

4. Biesma RG, Brugha R, Harmer A, Walsh A, Spicer N, Walt G: The effects of global health initiatives on country health systems: a review of the evidence from HIV/AIDS control. Health Policy \& Planning 2009, 24:239-252.

5. Atun R, Kazatchkine M: Promoting country ownership and stewardship of health programs: the Global Fund experience. Journal of Acquired Immune Deficiency Syndrome 2009, 52:S67-S68.

6. World Health Organization: The Global Fund's Strategic Approach to Health System Strengthening Consultation. World Health Organization Press: Geneva; 2007.

7. Hect R, Shah R: Recent trends and innovations in development assistance for health. In Disease Control and Priorities in Developing Nations. Edited by Breman D, Measham G, Alleyne G, Claeson M, Evans D, Jha P, Mills A, Musgrove P. Washington DC: The World Bank Press; 2007:243-258.

8. Le Loup G, Fluery S, Camargo K, Larouze B: International institutions, global health initiatives and the challenge of sustainability: lessons from the Brazilian AIDS programme. Tropical Medicine and International Health 2009, 15:5-10.

9. Gupta DG, Gostin L: How can donors help build global public goods in health? World Bank Policy Research Working Paper 4907 Washington. DC: The World Bank Press; 2009.

10. Gottret P, Schieber G: Health Financing Revisited Washington. DC: The World Bank Press; 2006.

11. Drager S, Gedik G, Dal Poz MR: Health workforce issues and the Global Fund to Fight AIDS, Tuberculosis and Malaria. Hum Resour Heal 2006, 4:1-12.

12. Brugha $R$, Donoghue $M$, Starling $M$, Ndubani $P$, Ssengoba F, Fernandes $B$, Walt G: The Global Fund: managing great expectations. Lancet 2004, 364:95-100.

13. Oluonzi SA, Macrae J: Whose policy is it anyway? International and national influences on health policy development in Uganda. Health Policy \& Planning 1995, 10:122-132.

14. Lieberman E: Boundaries of Contagion: Government Response to HIVIAIDS. Princeton: Princeton University Press; 2009.

15. McGuire J: Health. Wealth and Democracy in East Asia and Latin America New York: Cambridge University Press; 2010.

16. Oomann N, Bernstein M, Rosenzweig S: Seizing the Opportunity on AIDS and Health Systems. Washington DC: Center for Global Development; 2008.

17. Samb B, Evans T, Atun R, Dybul M: An assessment of interactions between global health initiatives and country health systems. Lancet 2009, 373:2137-2169.

18. Atun R, Weil DE, Eang MT, Mwakyusa D: Health-system strengthening and tuberculosis control. Lancet 2010, 375:2169-2178.

19. World Health Organization: Health Systems: Improving Performance. Geneva: World Health Organization Press; 2000.

20. Horton R: Venice statement: global health initiatives and health systems. Lancet 2009, 374:10-12.

21. Global Fund to Fight HIV/AIDS, Tuberculosis, and Maria: The Global Fund Strategic Approach to Health System Strengthening. Geneva: The Global Fund to Fight AIDS, Tuberculosis, and Malaria Press; 2007.

22. Smith O, Gbangbade S, Hounsa A, Miller-Franco L: Benin: System-wide Effects on the Global Fund. Bethesda: Partners for Health Reformplus, Abt Associates; 2005.

23. Stillman K, Bennet S: System-wide Effects of the Global Fund. Bethesda: Partners for Health Reformplus, Abt Associates; 2005.

24. World Health Organization: Interactions Between Global Health Initiatives and Health Systems: Evidence from Countries. Geneva:; 2010.

25. Siddiqi S, Masud T, Nishtar D, Peters B, Sabri K, Jama M: Framework for assessing governance of the health system in developing nations. Health Policy 2008, 90:13-25.

26. Dodgson R, Lee K, Dragger N: Global Health Governance: A Conceptual Review. Discussion Paper No.1. Geneva: World Health Organization; 2002.

27. Atkinson S, Fernandes L, Caprara A, Gideon J: Prevention and promotion in decentralized rural health systems: a comparative study from northeast Brazil. Health Policy \& Planning 2005, 20(2):69-79.

28. Guanais F, Macinko J: The health effects of decentralizing primary care in Brazil. Heal Aff 2009, 28(4):1127-35.

29. Rich J, Gómez EJ: Centralizing decentralized governance in Brazil. Publius: The Journal of Federalism 2012, 42(2):1-26. in press. 
30. Global Fund to Fight AIDS, Tuberculosis, and Malaria: The Framework Document of the Global Fund. Geneva: Global Fund to Fight AIDS, Tuberculosis, and Malaria Press; 2010.

31. Schocken C: Overview of the Global Fund to Fight AIDS, Tuberculosis, and Malaria Washington. DC: Center for Global Development; 2008.

32. Nunn R: The Politics and History of AIDS Treatment in Brazil. New York: Springer Press; 2009

33. Global Fund to Fight HIV/AIDS, Tuberculosis, and Malaria: Health Systems Funding Platform. Geneva: The Global Fund to Fight AIDS, Tuberculosis, and Malaria Press; 2010

34. Gómez E: Brazil's public option. Foreign Policy on-line 2009,

35. Patton MQ: Qualitative Research and Evaluation Methods. 3rd edition. Thousand Oaks: Sage Press; 2002.

36. Tarrow S: Bridging the quantitative-qualitative divide. In Rethinking Social Inquiry. Edited by Brady E, Collier D. New York: Rowman \& Littlefield Publishers; 2004

37. Atun $\mathrm{R}$, de Jongh TE, Secci FV, Ohiri K, Adeyi O, Car J: Integration of priority population, health and nutrition interventions into health systems: systematic review. BMC Publ Health 2011, 11:780.

38. International Treatment Preparedness Coalition (ITPC): Making Global Fund Country Coordination Mechanisms Work through Full Engagement of Civil Society. Brooklyn: International Treatment Preparedness Coalition Press; 2008

39. Atun $R$, de Jongh $T$, Secci FV, Ohiri K, Adeyi O: A systematic review of the evidence on integration of targeted health interventions into health systems. Health Policy \& Planning 2010, 25:1-14.

40. Atun R, de Jongh T, Secci F, Ohiri K, Adeyi O: Integration of targeted health interventions into health systems: a conceptual framework for analysis. Health Policy \& Planning 2010, 25(2):104-111.

41. Atun R, Bennett S, Duran A: When do Vertical (Stand-alone) Programmes have a Place in Health Systems? Copenhagen: World Health Organization Press; 2008.

42. Brinkerhoff D, Bossert T: Health Governance: Concepts, Experiences, and Programming Options Washington. DC: United States Agency for International Development; 2008.

43. United Nations Ddevelopment Program: Governance for Sustainable Human Development: A UNDP Policy Document. New York: UNDP Press; 1997.

44. Eichler R, Glassman A: Health Systems Strengthening via Performance-based Aid, Global health financing initiative working paper 3. Washington, DC: Brookings Institution Press; 2008.

45. Global Fund to Fight AIDS, Tuberculosis, and Malaria: An Evolving Partnership. Geneva: The Global Fund to Fight AIDS, Tuberculosis, and Malaria Press; 2007

46. Ooms G, VanDamme W, Baker B, Zeitz P, Schrecker T: The 'diagonal' approach to global fund financing: a cure for the broader malaise of health systems? Glob Heal 2008, 4:1-7.

47. Mann J, Tarantola D, Netter T: AIDS in the World. Cambridge: Harvard University Press; 1992.

48. Santos-Filho ET: Política da Tuberculose no Brasil: Uma Perspectiva da Sociedade Civil. New York: Research Report, Public Health Watch. New York: the George Soros Foundation/Open Society Institute; 2006.

49. Gómez EJ: Brazil's response to AIDS and tuberculosis: lessons from a transitional economy. In Health Systems and the Challenge of Communicable Diseases: Experiences from Europe and Latin America. Edited by Coker R, Atun R, McKee M. Berkshire: Open University Press; 2008

50. Global Fund to Fight AIDS, Tuberculosis, and Malaria: Fifth Call for Proposals. Geneva: Global Fund to Fight AIDS, Tuberculosis, and Malaria Press; 2005

51. Globo O: Governo lança plano de combate à tuberculose. 1999,

52. Serra J: Tuberculose: bicho-papão. Folha de São Paulo, April 2000, 2:1-3.

53. Leali F: Ministro da saúde admite aumento da tuberculose. Jornal do Brasil 1999,

54. Ruffino-Netto A, de Figueiredo Souza A: Evolution of the health sector and tuberculosis control in Brazil. Rev Panam Salud Publica 2001, 9:306-310.

55. Fundo Global Tuberculose Brasil: Entrevista: Ezio Távor. 2009,

56. Santos-Filho ET, Santos Gomes ZM: Strategies for tuberculosis control in Brazil: networking and civil society participation. Revista de Saúde Pública 2007, 41:1-6.

57. Massé M: From Cycles of Protest to Equilibrium: Explaining the Evolution of AIDS-related Non-governmental Organizations in Brazil. Oxford University: MPhil Thesis; 2009
58. Rich J: Re-examining the Link between Decentralization and Grassroots Participation in Brazil. University of California, Berkeley, Department of Political Science: Working Paper; 2009

59. Couttolenc B, La Forgia G, Matsuda Y: Brazil: raising the quality of public spending and resource management in the health sector. World Bank, En Breve 2007, 111:1-4.

60. Souza C: Brazil's Tax System: The Dilemmas of Policy Reform. Ottawa: Focal Policy Paper 05-02. Canadian Foundation for the Americas; 2005.

61. Faria VE: Institutional reform and government coordination in Brazil's social protection policy. Cepal Review 2002, 77:7-24.

62. Arretche M: Federalism, intergovernmental relations, and social policies in Brazil, Paper prepared for the seminar on Comparative Analysis of Inter-governmental Management Mechanisms and Formulation of Alternatives for the Brazilian Case 17-18 September. Ottawa: The Forum of Federations Press; 2003.

63. E Gómez: Testing an inter-dependent analytical approach to applying social science theories: explaining the evolution of NGOs, social movements, and government response to HIV/AIDS and Tuberculosis in Brazil. Journal of Health Politics, Policy \& Law (in press).

64. Fundo Global Tuberculose Brasil: Entrevista exclusiva: Draurio Barreira, coordinador do PNCT. 2009

65. Werlang P: Apresentação sobre Fundo Global. Paper presented at the II Simpósio Gaúcho de DST. 17-18. Brasilia, Brazil: Ministry of Health Press; 2009.

66. The CRAISnotícias webblog:, . http://criasnoticias.wordpress.com/2009/06/ 24/brasil-recife-debatera-controle-social-e-tuberculose-na-regiao-nordeste/.

67. Fundo Global Tuberculose Brasil: Entrevista do mês: José Temporão. 2008,

68. Tanaka O, Escobar EM, Aparecida S, Gimenez K, Lelli L, Yoshida T: Gerenciamento do setor saúde na década de 80, no Estado de São Paulo, Brasil. Revista de Saúde Pública 1992, 26:185-94.

69. Shiffman J: Has donor prioritization of HIV/AIDS displaced aid for other health issues? Health Policy \& Planning 2008, 23(2):95-100.

70. Gauri V, Lieberman E: Boundary politics and HIV/AIDS policy in Brazil and South Africa. Studies in Comparative International Development 2006, 41:47-73.

71. Formenti L: Fundo rejeita proposta do País para Aids. Brasil: O Estado de São Paulo Press; 2009.

72. Kaufman J: The role of NGOs in China's AIDS response. In Serving the People: State-society Negotiations and Welfare Provision in China. Edited by Schwartz J, Shawn S. New York: Routledge Press; 2009.

73. Weyland K: Social movements and the state: the politics of healthcare reform in Brazil. World Development 1995, 23:1699-1712.

74. Global Fund to Fight AIDS, Tuberculosis, and Malaria: Review of the Suspension/termination Processes for Global Fund grants. Geneva: The Office of the Inspector General; 2008.

75. Open Society: Examining the Impact of Global Fund Reforms on Implementation. New York: Open Society Foundation; 2011.

76. Gómez EJ: An alternative approach to evaluating, measuring, and comparing domestic and international health institutions: insights from social science theories. Health Policy 2011, 101:1-11.

\section{doi:10.1186/1744-8603-8-25}

Cite this article as: Gómez and Atun: The effects of Global Fund

financing on health governance in Brazil. Globalization and Health 2012 $8: 25$.

\section{Submit your next manuscript to BioMed Central and take full advantage of:}

- Convenient online submission

- Thorough peer review

- No space constraints or color figure charges

- Immediate publication on acceptance

- Inclusion in PubMed, CAS, Scopus and Google Scholar

- Research which is freely available for redistribution 